УДК 351.86:[351.77:314.2](477)

https://doi.org/10.52058/2708-7530-2021-11(17)-94-108

Кувшинова Свгенія Валентинівна студентка 2 потоку 1 групи, Київський національний університет ім. Т. Шевченка, Навчально-науковий інститут публічного управління та державної служби, виконавчий директор, Всеукраїнська благодійна організація «КОНВІКТУС УКРАЇНА», пр. Маяковського 7а., 170, м. Київ, 02225, тел.: (044) 592-58-47, evgeniua@gmail.com, https://orcid.org/0000-0002-9703-077X

\title{
НАПРЯМИ ВДОСКОНАЛЕННЯ СИСТЕМИ ГРОМАДСЬКОГО ЗДОРОВ'Я ЯК ЧИННИКА НАЦІОНАЛЬНОЇ БЕЗПЕКИ УКРАЇНСЬКОЇ ДЕРЖАВИ
}

Анотація. Глобальні виклики та наявні тенденції розвитку українського суспільства зумовлюють потребу в розгляді стану здоров'я населення 3 точки зору національної безпеки. Зазвичай національна безпека асоціюється 3 економічною, політичною або військовою галузями, але глобальна та національна безпека у сфері охорони громадського здоров'я може істотно впливати на економічну й політичну стабільність, а за масштабних чи повторних подій - і на демографічну.

Історично галузь охорони здоров'я України орієнтувалася на лікування захворювань, а не на їх попередження. Основні ресурси та законодавча база були спрямовані на лікування хвороб, водночас увага до збереження здоров'я була досить низькою. Завданням розпочатої 2015 року урядом України реформи була переорієнтація від політики лікування до політики збереження здоров'я й запобігання захворюванням [1]. Нова система громадського здоров'я будується на принципах децентралізації та субсидіарності, а важливим іiі компонентом є якісна зміна підходів до фінансування [2,3]. Розбудова такої системи громадського здоров'я в Україні є однією з вимог Угоди про асоціацію між Україною та Свропейським Союзом [4].

Стан здоров'я населення залежить від низки біологічних та соціальних причин, 3-поміж яких спадковість; середовище життєдіяльності (довкілля, соціально-економічне становище, у якому перебуває людина, iї рівень доходу, освіти, зайнятість, умови побуту й харчування), індивідуальна поведінка; організація медичної допомоги.

Система громадського здоров'я - цілісний комплекс інструментів, процедур і заходів, реалізованих державними організаціями та недержавними інституціями 3 метою запобігання захворюванням, зміцнення здоров'я населення, збільшення тривалості працездатного віку та підвищення особистої відповідальності громадян у збереженні власного здоров'я. У центрі уваги громадського здоров'я перебувають взаємодія різних установ та синхронізація зусиль. 
Існування пов'язаних зі здоров'ям проблем, які глобалізуються, тобто виходять за межі національних кордонів та загрожують світовій безпеці, висуває нові вимоги до державного управління в галузі громадського здоров'я.

Системна криза в охороні здоров'я безпосередньо впливає на національну безпеку держави через неспроможність практично всіх складників галузі здійснювати адекватну діяльність, спрямовану на збереження й укріплення здоров'я населення України.

Ключові слова: громадське здоров'я, система охорони здоров'я, здоров'я, населення, концепція, стратегія, угода, законопроєкт, національна безпека.

Kuvshynova Yevheniia Valentynivna Student of the 2nd stream of the 1st group, Kyiv National University named after T. Shevchenko. Educational and Scientific Institute of Public Administration and Civil Service, Executive Director, All-Ukrainian Charitable Organization "CONVICTUS UKRAINE", 7a Mayakovskoho Ave., 170, Kyiv, 02225, tel.: (044) 592-58-47, evgeniua@gmail.com, https://orcid.org/0000-0002-9703-077X

\section{DIRECTIONS FOR IMPROVING THE PUBLIC HEALTH SYSTEM AS A FACTOR OF NATIONAL SECURITY OF THE UKRAINIAN STATE}

Abstract. Global challenges and current trends in the Ukrainian society necessitate to consider the state of health of the population through the lens of the national security. National security is usually associated with economic, political or military sectors, but global and national security in the field of public health can have a significant impact on economic and political stability, and large-scale or repeated events can even affect the demographic stability.

Historically, Ukraine's healthcare sector has focused on treating diseases rather than preventing them. The main resources and legal framework were directed to the treatment of diseases, while maintaining people's health was a rather low priority. The task of the reform initiated by the Government of Ukraine in 2015 was to shift the healthcare policy from treatment-based one to the one focused on maintaining health and preventing diseases [1]. The new public health system is based on the principles of decentralization and subsidiarity, and a qualitative change in approaches to funding is its important component $[2,3]$. The development of such a public health system in Ukraine is one of the requirements of the Association Agreement between Ukraine and the European Union [4].

The state of health of the population depends on a number of biological and social reasons, including hereditary characteristics; living environment (environment, socio-economic situation of a person, their level of income, education, employment, living conditions and nutrition), individual behavior; organization of medical care. 
The public health system is a comprehensive set of tools, procedures and measures implemented by governmental organizations and non-governmental institutions to prevent disease, promote public health, prolong the working age and increase the personal responsibility of citizens in maintaining their own health. The focus of public health is on the interaction of different institutions and the synchronization of efforts.

The existence of health problems that are becoming increasingly global, that is, transcending national borders and threatening global security, creates new new demands for public administration in the field of public health.

The systemic crisis in health care directly affects the national security of the state due to the inability of almost all components of the healthcare sector to carry out adequate activities aimed at preserving and strengthening the health of the population of Ukraine.

Keywords: public health, health care system, health, population, concept, strategy, agreement, bill, national security.

Постановка проблеми. Проблематика громадського здоров'я незмінно має високу популярність як на міжнародному рівні, так і в Україні. Постійне існування загроз громадському здоров'ю від численних факторів (епідемій, інфекційних захворювань, поширення неінфекційних захворювань, біотероризму, впливу соціально-економічних детермінантів тощо) викликає необхідність приділення суттєвої уваги з боку національних та міжнародних інституцій. В Україні в процесі реформування національної системи охорони здоров’я питання громадського здоров'я також набувають нового значення. Громадське здоров'я вже не розглядають суто як діяльність із санітарноепідеміологічного нагляду.

3 початку XXI ст. вчені наголошували на необхідності кардинальних змін у системі охорони здоров'я з урахуванням відповідної європейської стратегії, пропонували шляхи реформування [5] акцентували на нагальній необхідності стандартизації медичної допомоги [6] тощо. Під системою громадського здоров'я розуміємо комплекс заходів, механізмів та інструментів, що здійснюються державними та неурядовими організаціями задля збереження i зміцнення здоров'я населення, профілактики захворювань, збільшення тривалості життя та формування навичок здорового способу життя [7]. Сучасне громадське здоров'я - це спроможність взаємодії різних установ громадського здоров’я, бригад громадського здоров’я, включаючи лікарів, інженерів громадського здоров'я, юристів у галузі громадського здоров'я, соціологів, фахівців із розвитку громад, із біоетики, представників неурядових організацій, громад тощо [8].

Роль державного управління охороною здоров'я у формуванні громадського здоров'я та національної безпеки беззаперечна.

Аналіз останніх досліджень і публікацій. Проблематиці громадського здоров’я присвячено значну кількість досліджень вітчизняних та зарубіжних 
науковців. Зокрема, увага вчених була спрямована на вивчення громадського здоров'я 3 позиції теорії та практики міжнародного права. 3-поміж них А. Бєляков, В. Ваді, Т. Гостін, Б. Мейер, Х. Кайон, Б. Тобес, А. Тєйлор, Д. Фідлер, Н. Хендель [9].

Сучасні науковці розглядають також проблеми пошуку дієвих механізмів державного управління у галузі охорони здоров'я. Це дослідження таких учених, як О. Баєва [10], М. Білинська, Д. Карамішев, Я. Радиш, Л. Мельник, I. Хожило, С. Мокрецов, I. Рожкова [5] 3. Надюк [11], С. Вовк [12,13], I. Фуртак [14], Н. Фещенко [15] та ін..

Мета статті - дослідження пріоритетних механізмів адаптації та подальшої імплементації світового досвіду в галузі громадського здоров'я. Надання рекомендацій щодо вдосконалення громадського здоров'я як чинника національної безпеки Української держави.

Виклад основного матеріалу. 1990 року у світі введено в практичний обіг термін «глобальний тягар хвороб» (Global Burden of Disease - GBD). Це комплексне поняття, яке сприяє формуванню уявлення про стан здоров'я людей, дає можливість дослідити найкращі стратегії для побудови здорового світу. Дослідження глобального тягаря хвороб дозволяє оцінити вплив факторів ризику на розвиток хвороб та розробити інноваційні системи вимірювання, які використовуватимуть для ухвалення рішень у системі громадського здоров'я. Проведені в цьому напрямі дослідження охоплюють 286 причин смерті, 369 захворювань і травм, 87 чинників ризику у 204 країнах. GBD - одне 3 найбільших наукових партнерств. Це співробітництво понад 5000 науковців зі 152 країн світу, які працюють із ВОО3 та іншими організаціями. Їхню діяльність, яка передусім полягає у виявленні кращих стратегій для побудови здорового світу, координує Institute for Health Metrics and Evaluation (IHME).

Україні GBD дозволяє ясніше встановлювати пріоритети для розвитку системи громадського здоров'я, з'ясовувати нові можливості комплексних оцінок ефективності роботи систем охорони здоров'я та їх зіставлення, а також виявляти найкращі практики організації медичної допомоги, порівнювати українські та закордонні заходи.

Висновки дослідження глобального тягаря хвороб у 2019 році вказують на те, що в Україні серцево-судинні захворювання $є$ основною причиною смертності населення. На жаль, ситуація не змінилася й у 2020-му. За цим показником наша країна лишається одним зі світових лідерів. Українці втрачають в рази більше років здорового життя через серцево-судинні захворювання, ніж сусідні країни та США. 3 огляду на це очевидним пріоритетним завданням у системі громадського здоров'я $\epsilon$ профілактика серцево-судинних захворювань, зниження економічних утрат держави через ці хвороби. Дані звіту також дають можливість сформувати державні програми як відповідь на ключові фактори ризику та реалізувати прицільні заходи для 
підвищення здоров'я населення як основного чинника національної безпеки держави [16].

Крім формування національної відповіді на основні фактори та причини смертності населення, в умовах зовнішніх загроз та непередбачуваних негативних явищ постає питання розбудови системи прогнозування, ідентифікації та управління небезпеками. До системи громадського здоров’я входять такі стратегічні сфери: нормативно-правова база; біологічна безпека та боротьба з інфекційними хворобами; протидія неінфекційним захворюванням; національна система крові; освіта. Усі ці сфери потребують розвитку в Україні та переформатування.

В умовах поширення коронавірусної хвороби ВОО3 випустила низку різних технічних посібників із заходів реагування на COVID-19. У них наведені інструменти координації, планування та моніторингу на рівні країн; нагляду для груп швидкого реагування та розслідування окремих випадків. Рекомендовані методи розвитку національних лабораторій; ведення пацієнтів; профілактики інфекцій та інфекційного контролю; протоколи ранніх розслідувань; інформування про ризики та роботу 3 населенням; надання оперативної підтримки та матеріально-технічного забезпечення; зниження ризику передачі від тварин до людини.

Країни мають можливість координувати зусилля та мати технічну підтримку міжнародної спільноти. В аналітичному документі «Посилення заходів щодо реагування систем охорони здоров'я на COVID-19» (рекомендації для Свропейського регіону ВО3 1 квітня 2020 року) зазначено рекомендації щодо відповіді систем на пандемію. У 16 рекомендаціях наведено характеристики COVID-19, наявні методики організації та фінансування системи охорони здоров'я, засновані на практичному досвіді та фактичних даних, а також інформація про методики екстреного реагування на COVID-19 у Свропейському регіоні та по всьому світу [17].

Варто зазначити, що Україні надають технічну підтримку у запровадженні рекомендацій ВОО3. Вона робить кроки у вибудові національної епідеміологічної служби як непорушної умови для комплексного управління відповіддю на інфекційні й неінфекційні хвороби, що загрожують національній безпеці країни та світу загалом. Так, основоположною зміною в напрямі формування національної епідеміологічної служби та запровадження системи громадського здоров’я став розроблений законопроєкт № 4142 «Про систему громадського здоров'я». Протягом трьох років Міністерство охорони здоров'я за підтримки міжнародних організацій працювало над адаптацією української системи охорони здоров’я до найкращих європейських практик. Цей законопроєкт $\epsilon$ критично важливим в умовах неухильного євроінтеграційного курсу України, протидії COVID-19 та загалом для збереження здоров'я населення. Законопроєкт був підтриманий Верховною Радою України в першому читанні в лютому 2021 року. 
Цей документ має на меті створення повноцінної національної епідеміологічної служби, побудову нової системи, з новими цінностями та відповідальностями. ДУ «Центр громадського здоров’я МО3 України» (ЦГЗ) діятиме як головна національна установа та забезпечуватиме координацію діяльності в рамках епідеміологічного нагляду та реагування на небезпеки спільно 3 регіональними Центрами контролю та профілактики захворювань (ЦКПЗ). ЦКПЗ будуть повністю відповідальні за рутинний моніторинг показників, прогнозування, виявлення надзвичайних ситуацій, спалахів та реагування на рівні регіонів. Завдання ЦКПЗ - аналізувати інформацію, на підставі якої пропонувати МО3 план дій стосовно нейтралізації ризиків у сфері громадського здоров’я. Тобто Україна планує створити сучасну систему реагування на загрози для здоров'я та протиепідемічного захисту. Водночас при розгляді законопроєкту було надано ряд важливих правок для доопрацювання. Найважливішими 3 них $\epsilon$ необхідність забезпечення незалежності структури громадського здоров'я, чітке підпорядкування на центральному та регіональному рівнях та прозорі зони відповідальності. Подальше ухвалення законопроєкту з урахуванням ключових рекомендацій експертів має ключове значення для побудови нової української системи громадського здоров'я.

Ще одне важливе питання для української системи громадського здоров'я - це питання належного фінансування галузі. Збільшення витрат на розвиток системи громадського здоров'я - пріоритетне завдання, над яким працює український уряд. Пандемія COVID-19 випробовує на міцність системи охорони здоров’я та соціального захисту світу, і наша країна, на жаль, не може продемонструвати міцні, сталі та повноцінні процеси. Всесвітня організація охорони здоров'я рекомендує витрачати на охорону здоров'я населення не менш ніж 6-6,5\% від валового внутрішнього продукту (ВВП). Проте, за даними 2020 року, Україна виділяє на ці потреби 3,2\% внутрішнього валового продукту, що значно менше, ніж у сусідніх країнах Центральної Європи. Аналізуючи дані витрат ВВП на охорону здоров'я в Україні за останні 7 років, можемо зробити висновки, що на 16,7\% знизились видатки на охорону здоров'я у 2020 році порівняно з 2015 роком. На 3\% зменшилась кількість населення. Отже, значно скоротилися консолідовані видатки на охорону здоров'я у відсотках від ВВП значно скоротилися (з 3,6\% до 3\%), а це говорить про той факт, що державні видатки на охорону здоров'я зростали набагато повільніше за економіку. Якщо така тенденція існуватиме й надалі, залишаючись на рівні 3\%, то очікувано, що реальні видатки на охорону здоров'я на одиницю населення зменшаться на 8,4\%. Паралельно із цим відбувається постійне скорочення консолідованих державних видатків на охорону здоров'я, недостатнє ресурсне забезпечення. Усі ці прогалини особливо гостро проявилися в умовах глобальної пандемії, тому вдосконалення фінансування охорони здоров'я набуває критичного значення [18]. 
Варто звернути увагу й на необхідність пошуку додаткових ресурсів для розвитку системи громадського здоров'я. Під час макрофіскальної нестабільності це залишається викликом як із політичної, так і з технічної точки зору. Можливості щодо збільшення загального обсягу державних видатків визначає наявний фіскальний простір. Вони залежать від макроекономічних показників країни та простору для додаткових державних видатків. Міжнародний валютний фонд (МВФ) визначає фіскальний простір як «простір для провадження дискреційної фіскальної політики стосовно існуючих планів без створення загрози для доступу до ринку та прийнятного рівня боргу» (МБФ 2018). Особливості ефективності управління закладами охорони здоров'я. [19]

Дослідження ВОО3 та Центру глобального розвитку демонструє, що загальні обсяги видатків, які зростають, зазвичай $є$ основним рушієм для збільшення асигнувань на охорону здоров'я, особливо в країнах із низьким та середнім рівнем доходів. Паралельно необхідно розвивати можливість збільшення видатків на охорону здоров’я завдяки кращому плануванню бюджету, упровадження більш ефективних правил управління державними фінансами [20].

Згідно $з$ даними Numbeo, що щорічно складає рейтинг якості життя серед країн, Україна за рівнем життя у 2016 році посіла 52 місце з 56, у 2017-му - 59 місце $з$ 67, у 2018-му - 57 місце з 60, у 2019-му - 62 місце 3 71. Рівень життя оцінюють за такими критеріями: клімат, рівень забруднення довкілля, купівельна спроможність населення, співвідношення цін на житло й доходу, вартість життя, рівень безпеки, якість охорони здоров'я, час у дорозі на роботу. В оцінці зазначено дуже низький індекс купівельної спроможності українців та високий індекс забруднення довкілля. Перше місце в рейтингу якості життя 2020 року посіла Данія. Лідерами також стали Швейцарія, Фінляндія, Австралія та Нідерланди. Аутсайдерами рейтингу є Кенія, Бангладеш і Нігерія [21].

Водночас експерти Міжнародного валютного фонду 2020 року спрогнозували, що у світі через пандемію COVID-19 збільшиться відстань між бідними та багатими, і вплив нинішньої пандемії на доходи населення буде значнішим, ніж попередніх.

Політика боротьби 3 бідністю безпосередньо стосується й проблем охорони здоров'я. Інвестиції в охорону здоров'я - важливий аспект економічного розвитку України та обов'язкова умова виходу з замкнутого кола бідності. Вирішення проблеми злиднів у контексті зміцнення здоров'я має першочергове значення, оскільки стан здоров'я людей, які живуть за межею бідності, завжди гірший і вмирають вони в більш молодому віці. Бідність не лише погіршує стан здоров'я загалом, а й збільшує ризик захворювання на вірусні гепатити, ВІЛ та туберкульоз. Через багатомісячну непрацездатність, утрату доходів і високі витрати на медичне обслуговування туберкульоз породжує бідність. Погані житлові умови та недостатнє харчування - 
додаткові, пов'язані зі злиднями, фактори ризику, які можуть призвести до туберкульозу.

Наслідком бідності може стати обмеження доступу до медичної допомоги, що призводить до затримок у діагностиці та лікуванні. Як результат - більш тривалий період бациловиділення та вища смертність. Високі ціни на патентовані лікарські засоби обмежують доступ до лікування, погіршують результати терапії та створюють величезні фінансові труднощі не лише для систем охорони здоров'я в країнах із низьким рівнем доходу, а й навіть у європейських країнах із високим рівнем доходу. Забезпечення людей, які живуть у бідності, доступом до недорогого та якісного медичного обслуговування недостатньо для покращення їхнього здоров'я. Основні детермінанти здоров'я залежать від дій поза сектором охорони здоров'я: доступне житло, освіта, продовольча безпека, безпечна питна вода, санітарія. Здоров'я бідних також можна покращити шляхом зменшення ризику розвитку залежності від тютюну чи алкоголю, отримання травм унаслідок ДТП чи інших видів травматизму, а також запобігання руйнівним наслідкам конфліктів та стихійних лих.

Відповідно до сказаного вище постає розуміння, що система громадського здоров'я та її ефективність залежить не лише від потужності медичної галузі, а й від міжгалузевої співпраці; від спроможності координувати дії із соціальною галуззю, фіскальною, пенітенціарною тощо. Міжсекторальна робота $\epsilon$ ключовим складником для розв'язання проблеми нерівності в отриманні допомоги. Велика кількість детермінант здоров'я перебуває за рамками обов'язків міністерства охорони здоров'я. Необхідність залучення інших секторів у роботу із соціальними детермінантами здоров'я вже давно визнана. У статті Алма-Атинської декларації 1978 р. (див. п. 1.2.) зазначено, що досягнення «найвищого можливого рівня здоров'я вимагає дій великої кількості інших соціальних та економічних секторів, крім сектора охорони здоров'я» (ВОO3 1978).

В Оттавській хартії зі зміцнення здоров'я 1986 року наголошувалося на необхідності державної політики з урахуванням аспектів здоров'я, зокрема в галузі транспорту, освіти та економіки [22].

Той же підхід відображено в проєкті з обліку інтересів здоров'я в усіх напрямках політики, вперше схваленої Фінляндією під час іiі головування в Європейській раді у 2006 р. [23] та Політичній декларації із соціальних детермінантів здоров'я, ухваленої під час Всесвітньої конференції із соціальних детермінантів здоров'я 2011 р. [24].

Проаналізуємо ретельніше, як Україна може досягти амбітних цілей у галузі охорони здоров'я. Першою стратегією може бути створення коаліцій із різних секторів. Вивчаючи досвід різних країн, можемо простежити, як, наприклад, подібні коаліції, створені в Ірландії, при співпраці політиків, громадськості та засобів масової інформації домоглися заборони на паління в 
громадських місцях та на робочих місцях, виступаючи проти потужної опозиції в особі тютюнової промисловості [25].

Другою стратегією має стати зміцнення міжсекторальної роботи через виявлення спільних цілей з іншими міністерствами та секторами. Визначення загальноважливих завдань різних секторів може сприяти залученню підтримки організацій поза Міністерством охорони здоров'я. Такі практичні приклади ми бачимо в Україні у сфері протидії ВІЛ-інфекціїСНІДу та туберкульозу, коли при наявності національного координаційного механізму - Національної ради 3 питань протидії ВІЛ-інфекції та туберкульозу - відбувається спільне узгодження напрямів роботи та дій як різних міністерств, так і організацій громадянського суспільства. Як результат, питання боротьби 3 ВІЛ та ТБ розглядається не лише в аспекті медичного характеру, а й у контексті боротьби 3 дискримінацією вразливих груп, забезпечення рівного доступу до медичної та соціальної допомоги, забезпечення створення комплементарних домедичних послуг, які дозволять людині вирішувати супутні потреби. Важливу роль тут відіграють і міжнародні організації, у координації з якими дії національних партнерів базуються на доказових даних та рекомендаціях.

Успішний досвід міжгалузевої співпраці необхідно розширювати й транслювати на таку сферу національної безпеки, як імунопрофілактика, що є пріоритетною для системи громадського здоров’я. Немає жодних сумнівів, що імунізація - це питання нацбезпеки. Згідно з підрахунками ВOO3, завдяки охопленню щепленнями щороку вдається зберегти 2-3 млн дитячих життів у світі. Загальновідомим є факт, що завдяки вакцинації людство позбавилося від натуральної віспи, а захворюваність на поліомієліт зменшилася на 99\%.

Звісно, у сьогоднішніх умовах пандемії нашій державі важливо забезпечити доступ до вакцини від COVID-19, проте не слід забувати й про обов’язкові щеплення: їх, згідно з обов'язковим календарем, від 10 . Крім того, постає важливе питання щодо проведення інформаційних кампаній, роз'яснень серед загального населення для розвінчування міфів щодо вакцин та формування належного рівня охоплення щепленнями. Для того, щоб забезпечити високий і справедливий рівень використання послуг вакцинації, необхідно зрозуміти, з якими перешкодами стикаються групи населення, де цей рівень недостатній. На основі такого аналізу можна виробити підходи, які стануть для громадян України джерелом підтримки та мотивації, нададуть їм можливості для отримання необхідних щеплень. Ці підходи повинні бути гарантією того, що всі групи населення будуть охоплені послугами імунізації, незалежно від рівня доходів та освіти, віку, місця проживання, етнічної приналежності, віросповідання.

Залучення організацій громадянського суспільства (ОГС) у процеси розбудови нової системи громадського здоров'я в Україні має ключове значення для охоплення профілактичними, лікувальними програмами спільнот, які піддаються ризику та $\epsilon$ важкодоступними групами. Роль громадянського суспільства також може полягати в підвищенні обізнаності та 
здійсненні профілактичних заходів, наданні послуг, зокрема й на базі спільнот, представленні інтересів ключових та вразливих груп населення; а також у агітації за усунення перешкод у доступі до послуг та сприянні доступу до недорогих та якісних лікарських засобів. Крім того, громадянське суспільство здатне брати участь в оперативних дослідженнях та пропаганді політики охорони здоров'я.

Організації громадянського суспільства відіграють важливу роль у забезпеченні відповідальності влади та установ за виконання взятих на себе зобов'язань. Виявлення найбільш релевантних організацій громадянського суспільства в національному контексті та їх довгострокове залучення до розробки й виконання планів дій може спричинити більш швидкий прогрес у досягненні мети. Як вже зазначалося вище, такі успішні приклади Україна має в напрямі зниження ризиків передачі ВІЛ, боротьби 3 туберкульозом та вірусними гепатитами. ОГС дається можливість обмеженої апробації ефективних втручань, які можуть виявитися гідними для розширення масштабів та сприяти адаптації вибраних національних стратегій.

До ОГС можуть належати пацієнтські групи різної спрямованості, такі як правозахисні, релігійні, молодіжні організації, організації, що займаються інформаційно-пропагандистською діяльністю, благодійні організації та фонди, професійні асоціації, організації, які присвятили свою діяльність гендерній проблематиці або питанням сексуального та репродуктивного здоров'я, добровольчі організації, що працюють з маргіналізованими групами, та багато інших [26].

Висновки. Міжнародні та європейські правові документи й політичні зобов'язання $є$ важливими орієнтирами для побудови системи громадського здоров'я та захисту здоров'я населення в Україні. Вони є орієнтирами для адаптації світового досвіду та врахування винесених уроків. Виконуючи ці зобов'язання, можна домогтися багато чого.

У сучасному світі державно-правове регулювання охорони здоров'я населення характеризується системністю в підходах та реалізації планових поетапних дій формування законодавства.

Затвердження в Україні довгострокової програми реформування галузі охорони здоров'я відповідно до цілей сталого розвитку на період до 2030 р. стало важливим кроком на шляху забезпечення розвитку системи громадського здоров’я. 3 орієнтацією на програму та світові напрацювання було розроблено проєкти нормативно-правових актів, прогнозних i програмних документів з метою забезпечення збалансованості економічного, соціального та екологічного вимірів сталого розвитку країни. Водночас слід зауважити, що в Україні немає повноцінної нормативно-правової бази, зокрема не вистачає Закону «Про громадське здоров’я» та підзаконних актів, які б визначали чітку інституційну структуру, яка б була незалежною та провідальною в розбудові нової системи, чітко координувала дії 3 
регіональними установами громадського здоров'я.

Потребує значної уваги одна з важливих функцій громадського здоров’я розвиток досліджень у сфері охорони здоров’я для наукового обгрунтування політики й практики. У рамках цієї функції ВОO3 вказує, що наукові дослідження мають найважливіше значення для обгрунтування політики та принципів надання послуг. 3 огляду на це інвестування в дослідництво та, як наслідок, застосування надалі цілісної системи ухвалення рішень на основі наукових даних має стати фокусом України на найближчі роки.

В умовах зовнішніх загроз та пандемії необхідно спиратися на наявні успішні практики всередині країни. Зокрема, досвід міжсекторальної співпраці та залучення ОГС до заходів боротьби з ВІЛ, ТБ, гепатитами може стати прикладом розбудови взаємодії різних секторів для досягнення спільних цілей у питаннях відповіді на пандемію. Тож одним із важливих завдань розбудови системи громадського здоров’я є виявлення найбільш релевантних організацій українського суспільства та довгострокове залучення їх до розробки й реалізації планів дій у галузі громадського здоров’я.

\section{Лimepamypa:}

1. Розпорядження КМУ від 30 листопада 2016 р. № 1002-р «Про схвалення Концепції розвитку системи громадського здоров'я» URL: https://www.kmu.gov.ua/npas/249618799

2. Побудова нової системи громадського здоров'я в Україні. URL: https://moz.gov.ua/ article/news/pobudova-novoi-sistemi-gromadskogo-zdorovja-v-ukraini

3. Ляшко В., Півень Н., Брага М., Рижкова А., Нагорна I., Приходько В., Сорока I., Глембоцька Г., Короленко В. Розробка та фінансування регіональних і місцевих програм громадського здоров'я : операційний посіб. 60 c. URL : https://bit.ly/3ChxVdw

4. Угода про асоціацію між Україною, з однієї сторони, та Європейським Союзом, Свропейським співтовариством 3 атомної енергії і їхніми державами-членами, 3 іншої сторони. URL: https://zakon.rada.gov.ua/laws/show/984_011\#Text

5. Державна політика у сфері охорони здоров'я : кол. моногр. : у 2 ч. / заг.ред. проф. М. М. Білинської, проф. Я. Ф. Радиша. Київ : НАДУ, 2013. Ч. 1. 396 с. URL: http://academy.gov.ua/NMKD/library_nadu/Monogr/457d99ff-a477-4205-baaf-2cee246fe3da.pdf

6. Ярош Н. П., Лупей-Ткач С. І. Сучасний стан, проблеми стандартизації медичної допомоги та шляхи їх вирішення в умовах реформування системи охорони здоров'я України. Україна. Здоров’я нації. 2012. № 1 (21). С.95-100.

7. Медична реформа. Урядовий портал. URL: https://www.kmu.gov.ua/ diyalnist/reformi/rozvitok-lyudskogo-kapitalu/reforma-sistemi-ohoroni-zdorovya

8. Закон України «Про внесення змін до деяких законодавчих актів України щодо удосконалення законодавства 3 питань діяльності закладів охорони здоров'я» від 06.04. 2017 № 2002-VIII. URL: https://zakon.rada.gov.ua/laws/show/2002-19\#Text

9. Демченко I. Громадське здоров'я: міжнародно-правові підходи до визначення. Scientific Papers of the Legislation Institute of the Verkhovna Rada of Ukraine. 2018. № 2. C. 53-58. URL: http://ir.librarynmu.com/bitstream/123456789/824/1/DemchenkoGromadskezdorovyamizhp ravpidhody.pdf

10. Баєва О. Формування напряму та стратегії підготовки менеджерів для галузі охорони здоров’я. Вісник УАДУ. 2003. № 1. С. 233-236. 
11. Надюк 3. О. Механізми державного регулювання ринку медичних послуг в Україні: дис... д-ра наук : 25.00.02. / Класич. приват. ун-т. Запоріжжя, 2009. 469 с.

12. Вовк С. М. Сучасна євроінтеграція системи охорони здоров'я. Україна та ЄС: можливості та перспективи співпраці : зб. матеріалів, доповідей Інтернет-конференції в рамках проекту «Кафедра Жана Моне «Аналіз та застосування європейського досвіду демократії та належного врядування в Україні» (18-19 трав. 2017 р., м. Маріуполь). Маріуполь : ДонДУУ, 2017. С. 209-212.

13. Вовк С. М. Процесс системной трансформации здравоохранения в переходный период. Економіка і право охорони здоров’я. 2015. № 1 (1). С.11-14.

14. Фуртак I. I. Механізми державного управління охороною здоров'я в Україні. Медичне право України: проблеми становлення та розвитку: матеріали I Всеукр. наук.практ. конф. (19 - 20 квіт. 2007 р., м. Львів). Львів, 2007. С. 318-323.

15. Фещенко Н. М. Галузь охорони здоров'я: проблеми та перспективи фінансового забезпечення. Держава та регіони. 2010. № 3. URL: http://ir.znau.edu.ua/bitstream/123456789/ 2559/1/Derzhava\%20ta\%20regioni_2010_6_155-161.pdf

16. Global health: time for radical change? The Lancet. Article, 2020. URL: https://www.thelancet.com/journals/lancet/issue/vol396no10258/PIIS0140-6736(20)X0042-0

17. Усиление мер реагирования систем здравоохранения на COVID-19. Рекомендации для Европейского региона ВОЗ. Аналитическая записка. Копенгаген : Европейское региональное бюро ВО3, 2020. Лицензия: CC BY-NC-SA 3.0 IGO.

18. Москаленко В. Ф., Грузєва Т. С., Іншакова Г. В. Регламентація права на охорону здоров'я у міжнародних правових актах. Медичне право України та його законодавче забезпечення (генезис, розвиток, проблеми і перспективи вдосконалення) : матеріали II Всеукр. наук.-практ. конф. 3 медичного права (м. Львів, 17-18 квіт. 2008 р.). С. 186-201. Львів, 2008. URL: http://medicallaw.org.ua/uploads/media/02_186_01.pdf

19. Медяник Д. І., Липчанський В. О. Особливості ефективності управління закладами охорони здоров’я. Наукові записки : зб. наук. праць. Кіровоград : КНТУ, 2016. Вип. 19. С. $23-29$.

20. Primary Health Care on the Road to Universal Health Coverage 2019: Monitoring report od World Health Organization. URL: https://www.who.int/healthinfo/universal_health_coverage/ report/uhc_report_2019.pdf?ua=1

21. Cost of Living in Ukraine. NUMBEO. URL: https://www.numbeo.com/cost-ofliving/country_result.jsp?country=Ukraine

22. Оттавская хартия по укреплению здоровья, $1986 \quad$ г. URL: https://www.euro.who.int/_data/assets/pdf_file/0009/146808/Ottawa_Charter_R.pdf

23. Аделаидское заявление «Учет интересов здоровья во всех направлениях политики» на пути к совместному управлению в интересах здоровья и благополучия URL: https://www.who.int/social_determinants/publications/isa/russian_adelaide_statement_for_web.pdf

24. Социальные детерминанты здоровья: итоги Всемирной конференции по социальным детерминантам здоровья (Рио-де-Жанейро, Бразилия, октябрь 2011 г.). URL: https://apps.who.int/gb/ebwha/pdf_files/EB130/B130_15-ru.pdf?ua=1

25. Аспекты общественного здравоохранения в Европе. ВОЗ,Европейская Обсерватория по системам и политике здравоохранения, под редакцией Bernd Rechel и Martin McKee, 2018.

26. Межсекторальное взаимодействие, направленное на ликвидацию ВИЧ-инфекции, туберкулеза и вирусных гепатитов в Европе и Центральной Азии. Концептуальная основа реализации Общей позиции Организации Объединенных Наций. 92 с. URL: https://apps.who.int/iris/bitstream/handle/10665/337387/9789289055338-rus.pdf

27. Кухарєва О.О. Тенденції зовнішньоекономічної безпеки України // Бізнес-навігатор. - Випуск 3 (64) (2021). - С. 75-79. 


\section{References:}

1. Rozporyadzhennya KMU vid 30 listopada 2016 r. № 1002-r «Pro skhvalennya Koncepciï rozvitku sistemi gromads'kogo zdorov’ya» [Ordering of CMU from 30 leaf fall 2016 p. № 1002-r "About the concept of development of the system of community health"] Retrieved from https://www.kmu.gov.ua/npas/249618799 [in Ukrainian].

2. Pobudova novoï sistemi gromads'kogo zdorov'ya v Ukraïni. [Promoting new systems of community health in Ukraine]. Retrieved from https://moz.gov.ua/article/news/pobudova-novoisistemi-gromadskogo-zdorovja-v-ukraini [in Ukrainian].

3. Lyashko V., Piven' N., Braga M., Rizhkova A., Nagorna I., Prihod'ko V., Soroka I., Glemboc'ka G., Korolenko V. [Lyashko V., Piven N., Braga M., Rizhkova A., Nagorna I., Prikhodko V., Soroka I., Glembotska G., Korolenko V.] Rozrobka ta finansuvannya regional'nih $i$ miscevih program gromads'kogo zdorov'ya : operacijnij posib. - Development and financing of regional and microbial health programs: operational posib. 60 p. Retrieved from https://bit.ly/3ChxVdw [in Ukrainian].

4. Ugoda pro asociaciyu mizh Ukraïnoyu, z odniєï storoni, ta Evropejs'kim Soyuzom, Evropejs'kim spivtovaristvom z atomnoï energiï i ïhnimi derzhavami-chlenami, z inshoï storoni. [Pleasure for the association between Ukraine, from one side, and the European Union, the European trade in nuclear energy and other member states, from the other side[. Retrieved from https://zakon.rada.gov.ua/laws/show/984_011\#Text [in Ukrainian].

5. Derzhavna politika u sferi ohoroni zdorov'ya : kol. monogr. : u 2 ch. [State policy in the sphere of health protection: count. monograph : at $2 \mathrm{~h} /$ zag.ed. prof. M. M. Bilinskoi, prof. Ya.F. Radisha. Kiev: NADU, 2013. Part 1. 396 p.] Retrieved from http://academy.gov.ua/NMKD/ library_nadu/Monogr/457d99ff-a477-4205-baaf-2cee246fe3da.pdf [in Ukrainian].

6. YArosh N. P., Lupej-Tkach S. I. [Yarosh N. P., Lupei-Tkach S. I.] Suchasnij stan, problemi standartizaciï medichnoï dopomogi ta shlyahi ïh virishennya $v$ umovah reformuvannya sistemi ohoroni zdorov'ya Ukraïni - The current country, the problems of standardization of medical aid, and the paths and trends in the minds of the reform of the health protection system of Ukraine. Ukraine. Health of the nation. 2012. No. 1 (21). Pp. 95-100. [in Ukrainian].

7. Medichna reforma. Uryadovij portal. [Medical reform. Uryadovy portal.] Retrieved from https://www.kmu.gov.ua/diyalnist/reformi/rozvitok-lyudskogo-kapitalu/reforma-sistemi-ohoronizdorovya [in Ukrainian].

8. Zakon Ukrainy «Pro vnesennya zmin do dejakuch zakonodavchish aktiv Ukrainu shchodo ydoskonalennia dijalnosti zakladiv ochronu zdorovia» [Law of Ukraine "On the introduction of amendments to the acts of legislation of Ukraine for the improvement of legislation on nutrition and health protection"] dated 06. 04. 2017 No. 2002-VIII. Retrieved from https://zakon.rada.gov.ua/laws/show/2002-19\#Text [in Ukrainian].

9. Demchenko I. Gromads'ke zdorov'ya: mizhnarodno-pravovi pidhodi do viznachennya. [Hromadske health: international legal go to the appointment]. Scientific Papers of the Legislation Institute of the Verkhovna Rada of Ukraine. 2018. No. 2. P. 53-58. Retrieved from http://ir.librarynmu.com/bitstream/123456789/824/1/DemchenkoGromadskezdorovyamizhpravpid hody.pdf [in Ukrainian].

10. Bajeva O. Formuvannya napryamu ta strategiï pidgotovki menedzheriv dlya galuzi ohoroni zdorov'ya. [Formation of direct training strategies for managers for health protection]. Visnik UADU. 2003. No. 1. P. 233-236. [in Ukrainian].

11. Nadyuk Z.O. Mekhanizmi derzhavnogo regulyuvannya rinku medichnih poslug $\mathrm{v}$ Ukraïni [ Mechanism of sovereign regulation of the market of medical services in Ukraine:] dis ... Doctor of Science: 25.00.02. / Klasich. private un-t. Zaporizhzhya, 2009.469 p. [in Ukrainian].

12. Vovk S. M. Suchasna evrointegraciya sistemi ohoroni zdorov'ya. Ukraïna ta ES: mozhlivosti ta perspektivi spivpraci [Suchasna Eurointegration of health protection systems. Ukraine and EC: Possibilities and perspectives of spivpratsi:] zb. materials, additional information 
on the Internet-conference within the framework of the project "Jean Monnet Chair" Analysis and Consolidation of European Doctrine of Democracy and Decent Implementation in Ukraine "(1819 may. 2017 p., m. Mariupol). Mariupol: DonDUU, 2017, pp. 209-212. [in Ukrainian].

13. Vovk S. M. Process sistemnoj transformacii zdravoohraneniya v perekhodnyj period. Ekonomika i pravo ohoroni zdorov'ya. [The process of systemic transformation of health care in the transition period. Economics and the right to protect health.] 2015. No. 1 (1). Pp. 11-14. [in Ukrainian].

14. Furtak I. I. Mekhanizmi derzhavnogo upravlinnya ohoronoyu zdorov'ya v Ukraïni. Medichne pravo Ukraïni: problemi stanovlennya ta rozvitku: [Mechanisms of sovereign management of health protection in Ukraine]. Medical law of Ukraine: problems of formation and development: materials I Vseukr. nauk.-practical. conf. (19 - 20 apr. 2007 p., Metro Lviv). Lviv, 2007. S. 318-323. [in Ukrainian].

15. Feshchenko N. M. Galuz' ohoroni zdorov'ya: problemi ta perspektivi finansovogo zabezpechennya. Derzhava ta regioni. [Galuz protect health: problems and prospects of financial health. The state of the region.] 2010. No. 3. Retrieved from http://ir.znau.edu.ua/bitstream/ 123456789/2559/1/Derzhava\%20ta\%20regioni_2010_6_155-161.pdf [in Ukrainian].

16. Global health: time for radical change? The Lancet. Article, 2020. Retrieved from https://www.thelancet.com/journals/lancet/issue/vol396no10258/PIIS0140-6736(20)X0042-0

17. Usilenie mer reagirovaniya sistem zdravoohraneniya na COVID-19. Rekomendacii dlya Evropejskogo regiona VOZ. [Strengthening the health systems response to COVID-19. Recommendations for the WHO European Region.] Analiticheskaya zapiska - Analytic note. Copenhagen: WHO Regional Office for Europe, 2020. License: CC BY-NC-SA 3.0 IGO. [in Russian].

18. Moskalenko V. F., Gruzova T. S., Inshakova G. V. Reglamentaciya prava na ohoronu zdorov'ya u mizhnarodnih pravovih aktah. Medichne pravo Ukraïni ta jogo zakonodavche zabezpechennya (genezis, rozvitok, problemi i perspektivi vdoskonalennya [Regulation of the right to health protection in international legal acts. Medical law of Ukraine and its legal protection (genesis, development, problems and perspectives thoroughly)]: materials II Vseukr. nauk.practical. conf. medical law (m. Lviv, 17-18 sq. 2008 p.). S. 186-201. Lviv, 2008. Retrieved from http://medicallaw.org.ua/uploads/media/02_186_01.pdf [in Ukrainian].

19. Medyanik D. I., Lipchanskiy V. O. Osoblivosti efektivnosti upravlinnya zakladami ohoroni zdorov'ya [Special features of the efficiency of managing mortgages for health protection]. Naukovi zapiski : zb. nauk. prac' - Science notes: zb. sciences. pr. Kirovohrad: KNTU, 2016. Vip. 19.P. 23-29. [in Ukrainian].

20. Primary Health Care on the Road to Universal Health Coverage 2019: Monitoring report od World Health Organization. Retrieved from https://www.who.int/healthinfo/universal_ health_coverage/report/uhc_report_2019.pdf?ua=1

21. Cost of Living in Ukraine. NUMBEO. Retrieved from https://www.numbeo.com/costof-living/country_result.jsp?country=Ukraine

22. Ottavskaya hartiya po ukrepleniyu zdorov'ya, 1986 g. [Ottawa Charter for Health Promotion 1986] Retrieved from https://www.euro.who.int/data/assets/pdf_file/0009/146808/ Ottawa_Charter_R.pdf [in Russian].

23. Adelaidskoe zayavlenie «Uchet interesov zdorov'ya vo vsekh napravleniyah politiki» na puti $\mathrm{k}$ sovmestnomu upravleniyu v interesah zdorov'ya i blagopoluchiya [Adelaide Statement on Health in All Policies Towards Collaborative Governance for Health and Well-being] Retrieved from https://www.who.int/social_determinants/publications/isa/russian_adelaide_statement_for_web.pdf [in Russian].

24. Social'nye determinanty zdorov'ya: itogi Vsemirnoj konferencii po social'nym determinantam zdorov'ya [Social Determinants of Health: Outcome of the World Conference on Social Determinants of Health] (Rio de Janeiro, Brazil, October 2011). Retrieved from https://apps.who.int/gb/ebwha/pdf_files/EB130/B130_15-ru.pdf?ua=1 [in Russian].

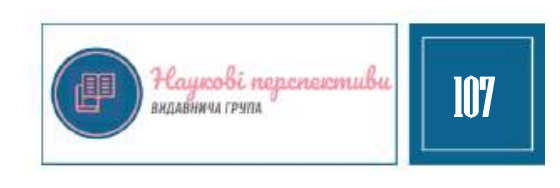


25. Aspekty obshchestvennogo zdravoohraneniya $\mathrm{v}$ Evrope. VOZ,Evropejskaya Observatoriya po sistemam i politike zdravoohraneniya [Aspects of public health in Europe. WHO, European Observatory on Health Systems and Policies], edited by Bernd Rechel and Martin McKee, 2018. [in Russian].

26. Mezhsektoral'noe vzaimodejstvie, napravlennoe na likvidaciyu VICH-infekcii, tuberkuleza i virusnyh gepatitov v Evrope i Central'noj Azii. Konceptual'naya osnova realizacii Obshchej pozicii Organizacii Ob"edinennyh Nacij. [Intersectoral interaction aimed at elimination of HIV infection, tuberculosis and viral hepatitis in Europe and Central Asia. Conceptual framework for the implementation of the United Nations Common Position.] 92 s. Retrieved from https://apps.who.int/iris/bitstream/handle/10665/337387/9789289055338-rus.pdf [in Russian].

27. Kuhareva, O.O. (2021). Tendenciï zovnishn'oekonomichnoï bezpeki Ukraïni [Trends in foreign economic security of Ukraine]. Biznes-navigator - Business Navigator, 3 (64) (2021), 75-79 [in Ukrainian]. 